\title{
Are there Jews and Christians \\ in the Bible?
}

\section{John J Pilch \\ Department of Biblical Literature, Georgetown University, Washington, DC}

\begin{abstract}
The article shows that it is anachronistic to speak of either 'Christians' or 'Jews' in the biblical period. In the New Testament both words are used pejoratively by outsiders. However, it became appropriate to speak of 'Jews' when referring to the period of Rabbinic Judaism onwards, and of 'Christians' since the christological debates of the fourth century $C E$. 'Israel' was the in-group name during the Second Temple period. Outsiders, like the Romans, called the entire land 'Judea' and all its inhabitants 'Judeans'. Members of the 'house of Israel' called all outsiders 'non-Israel' or 'the nations'. The article concludes with a discussion of the ancient point of view of labeling persons.
\end{abstract}

\section{INTRODUCTION}

On Pentecost Sunday, 1995, in the Cathedral of Mary Our Queen, Baltimore, MD, the preacher read the assigned gospel (John 20:19-23) which reports that after the death of Jesus, the disciples gathered behind locked doors 'for fear of the Jews'. In his homily the preacher explained: "The use of the term "the Jews" is not meant to apply to the Jewish people as such, but to the people who sought Jesus' death'.

A Jewish woman in the congregation that day to witness.her granddaughter's first Holy Communion took offense and registered complaints with the Archbishop and the local chapter of the American Jewish Committee. The preacher replied in writing with an apology and an explanation that he weighed his words carefully because he was quite aware of the Church's official repudiation of laying blame for the death of Jesus on the Jews as a people.

* Dr John J Pilch teaches biblical literature at Georgetown University, Washington, DC. He is the author of 'The Transfiguration of Jesus: An experience of alternate reality,' in Modelling Early Christianity: Social Scientific Studies of the New Testament in its Context, Philip F Esler, (ed), (London and New York: Routledge, 1995) and other articles and books, including two best sellers: Introducing the Cultural Context of the Old Testament and Introducing the Cultural Context of the New Testament (Paulist, 1991). 
The American Jewish Committee and Christian groups planned to sponsor preaching colloquiums prior to the next liturgical seasons of Advent and Lent in order to head-off 'anti-Judaic bias' that is sometimes heard in Christian sermons during those times.

\section{A PERENNIAL PROBLEM}

This episode reflects a perennial problem that appears to have emerged with greater intensity in Catholic congregations since the reforms of the Second Vatican Council. The problem is especially acute when the Gospel of John is read, for John uses the word 'the Jews' seventy-one times, more frequently than any other book of the New Testament. In thirty-seven instances, the term describes authoritative groups whom 'other Jews' fear (the preacher's point above in John 20:19).

Johannine scholar, U C von Wahlde, studied these occurrences intensely and distinguished a variety of meanings in John's gospel. He concluded that sometimes the

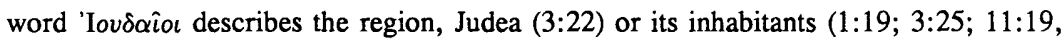
$31,33,36,45,54)$. At other times it has a national or religious sense $(2: 6,13 ; 5: 1$; $6: 4 ; 7: 2 ; 11: 55 ; 19: 40,42)$. [This meaning is debatable because the concept of 'nation' is a relatively recent one, and 'religion' in the ancient world was a social institution embedded in 'politics' and not 'free-standing' as in the modern West.] Finally, at still other times it carries an overtone of hostility when, for instance, it describes the

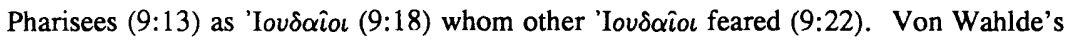
purpose was to use these shifts of meaning, ideology, and theology to identify and sort out the different traditions which the Johannine redactor compiled into the final edition of this gospel. Would his article be helpful for teachers and preachers? Perhaps not.

\section{A FRESH INSIGHT}

Increasing numbers of contemporary biblical scholars observe that the problems raised by the term 'the Jews' in the Bible is specious, and its various tortuous solutions unsuccessful and indeed unnecessary. The real problem lies with translators and interpreters who share contemporary Western culture's lack of historical sense and ethnocentric tendencies.

The Hebrew word, יהורים, and the Greek word, 'Iovסaio, should be properly translated Judean. The contemporary English word, Jew, is traced linguistically to the Middle English period (c 1200 C E) deriving from the Old French Giu, Juiu, and ultimately back to the Latin, Greek, and Hebrew, but it is not an appropriate translation of the Latin, Greek and Hebrew words. 
All language derives its meaning not from dictionaries and etymologies but rather from the social system. Westerners living in the 20th century world do indeed know Jews and Jewish beliefs and practices. Yet contemporary Jewish scholars like Shaye Cohen and Jacob Neusner remind us that contemporary Jewish beliefs and practices are rooted in the formation of the Babylonian Talmud of the sixth century C E, a process that began with the compilation of the Mishna late in the first century of the common era. Some of these practices, like the bar and especially the bat mitzvah, have no root in the Hebrew Bible or the historical periods of its various settings.

Similarly, it was also late in the first century of the common era that Rabbis, as we know and understand them, and the Synagogue as a place of worship began to develop. The title Rabbi given to John the Baptist (Jn 3:26), Jesus (Mt 26:25, 49), and others (Mt 23:7) was nothing more than a respectful way of addressing important teachers. It derives from the Hebrew word, ברุ, meaning 'lord, master'.

As for the synagogue, Heather McKay has demonstrated that in Jesus' day and until the year 200 , it was like a community center where men gathered to read and listen to Torah, dispute and argue with others ( $\mathrm{Lk}$ 4:16-30 and par). They did not gather for services because none existed at this time. Sabbath was a day of rest. It became a day of worship in reaction to the practice of the Messianic group (usually called Christians) in Palestinian Yahwism who assembled to celebrate the Lord's Supper on the first day of the week.

It is equally anachronistic to speak of Christians in the biblical period, since that term as it is understood today emerged only from the christological debates of the fourth century C E, particularly from the question: how did Jesus of Nazareth relate to Yahweh the God of Israel? It is clear from Acts 11:26 that the name was given to the group by outsiders, and in Acts 26:28 the outsider, Agrippa uses it in a mocking sense. In 1 Peter 4:16-17, it appears again with a clearly pejorative meaning, best translated as 'Christ-lackeys'. Thus in biblical times and texts there existed neither 'Jews' nor 'Christians' as these terms are understood and used today. First century Yahwism included a variety of groups: Pharisaic, Messianic (called christian), Sadducaic, Essene, among others.

\section{THE PAST}

How then are we to speak of the past: the time of Jesus? the time of the Old Testament? Contemporary scholars propose a major, three fold division of Jewish history with regard to proper terminology. 
* The Period of the First Temple ( 950 B C E - 586 B C E) is the period of First Temple religion. It extends from the completion of the First Temple under Solomon to the time of that Temple's destruction by invading Babylonian armies. The country is known as Israel. The people of this period are described as Israelites (literally 'sons or people of Israel' in the Hebrew Bible). Their religious beliefs and practices are properly called Israelite religion. With the Temple as the focal point, Temple sacrifices, Pilgrimage festivals, and similar practices dominate political religion. Domestic religion centers on ancestrism rooted in burial in the family grave (Gen 49:29-33).

* The Period of the Second Temple (520 B C E - 70 C E) marks the period of Second Temple religion. It extends from the completion of the Second Temple under Ezra and Nehemiah to the destruction of the temple by Titus. The country is called Judea and its inhabitants are called Judeans. The religion is properly calledJudean or Judaic religion.

* The period of Rabbinic Judaism (6th century C E Babylonian Talmud beginning perhaps as early as $90 \mathrm{C} \mathrm{E}$ - the date of the reputed gathering of the so-called Council of Jamnia - and continuing to the present day). The religion of this period is currently termed 'normative Judaism' deriving from Pharisaic scribalism which is the foundation of contemporary Jewish belief and practice. It is this form of Judaism and these Jews that are familiar to the contemporary world. In the modern day, the terms Jewish religion, Jewish beliefs, et cetera, are most appropriate but cannot and should not be retrojected into the Bible. Such anachronism, however, is unfortunately too common in many religious education programs.

\section{INSIDERS AND OUTSIDERS}

When analyzing societies and cultures, anthropologists observe how people distinguish between ingroups and outgroups, insiders and outsiders. This distinction is very useful in understanding the terminology proposed above.

Insiders, particularly those who embraced and practiced Second Temple religion, generally referred to themselves as the 'people of Israel' (e g, Ezr 2:1; 3:1; etc) or as members of 'the house of Israel' (Mt 10:6). Israel was thus an ingroup name (see Jn 1:47). Fellow ethnics who mocked Jesus called him 'King of Israel' (Mt 27:42). Insiders or ingroup members were very kind and very loyal to each other especially when in need (Lk 11:5-9). Such behavior is rarely extended to outsiders. The whole house of Israel was one big ingroup even though its boundaries were fluid and always shifting. 
The first century 'house of Israel' ingroup recognized three geographical divisions: Judea, Perea, and Galilee. The people living in these areas also represented three ingroups within the overall ingroup of the house of Israel. What they had in common was birth into one people known as the 'house of Israel' and allegiance to the Jerusalem Temple. The parable of the Good Samaritan (Lk 10:29-37) tries to address a common question: who belongs in Israel? From this ingroup perspective, in the House of Israel, Jesus the Galilean was put to death by outsiders (Romans) at the instigation of some Judeans.

It is important to note that the ingroup name also applied to emigres living in various colonies outside the country as well as members of the house of Israel born outside the country. Paul of Tarsus commonly identified himself as a Hebrew or Israelite (2 Cor 11:22; Phlp 3:5; Rm 11:1).

Jesus was not a Judean, yet the title placed upon his cross read: 'Jesus of Nazareth, King of the Judeans' (Mt 27:37; Mk 15:26; Lk 23:38; Jn 19:19). Notice the objection that Jesus' opponents make in John. They know full well he is a Galilean, but they do not ask Pilate to change the wording 'king of Judeans' to 'king of Galileans'. Instead they ask only to indicate that Jesus made such a claim.

What Jesus' opponents highlight is the outgroup or outsider practice which the insiders accept. Outsiders, like the Romans, called the entire land Judea and all its inhabitants Judeans. Paul also accepted the outsider usage (Ac 22:3; Gl 2:15) and identified himself accordingly. Outsiders justified this global term for the entire country and all its inhabitants as well as those with ethnic roots here but living elsewhere because they all affirmed allegiance to the God of Israel in Jerusalem in Judea. Ingroup members accepted this designation, Judean, because their Temple, the focalpoint of their beliefs and practices was located here.

Members of the ingroup known as house of Israel similarly lumped all outsiders into a large group called non-Israel or 'the nations' (Hebrew goyîm; Greek ethnoi; English 'gentiles') ignoring all distinctions. The same is true of the various Hellenicpeople lumped together as 'Greeks' or 'Hellenes' and their typical behavior described as 'Hellenism'. Such stereotyping is normal for group-centered cultures such as those reflected in the Bible and is part and parcel of the insider-outsider perspective.

\section{IDENTIFYING PEOPLE IN ANTIQUTTY}

The ingroup/outgroup terminology proposed above is intelligible from the ancient point of view because, generally speaking, ancient Mediterranean people tended to identify and label persons and animate beings primarily in terms of their geographic place of origin. Simon of Cyrene lent a helping hand to Jesus (Mt 27:32). Jesus was called the 
Nazarean or man from Nazareth (Mt 21:11; Mk 1:24; 10:47; Lk 24:19; etc). He was also called a Galilean (Mt 26:69): Outsiders (the Romans) called him (and everyone in that country, or for whom this was their country of ethnic origin) a Judean (Mt 27:29, 37).

Another way of identifying people was by their family. 'Is this not Joseph's son?' (Lk 4:22), or 'is this not the carpenter's son? Is not his mother called Mary? And are not his brothers James and Joseph and Simon and Judas? And are not all his sisters with us?' (Mt 13:55-56). We also recognize Simon bar Jonah (Mt 16:17), James and John the sons of Zebedee (Mk 10:35), and the blind man Bar-Timaeus known only by his father and not by his own name (Mk 10:46).

Yet a third way of identifying people was by their group. 'Is this not the carpenter ...?' (Mk 6:3). Similar group designations include: a lawyer (Lk 10:25), a Levite (Lk 10:32), a Pharisee (Lk 11:37), a tax-collector (Lk 18:10), a leper (Mt 26:6), and so

on. Paul sometimes identified himself by his group: Pharisee (Phlp 3:5; Ac 23:6; see also Ac 22:3), but as Paul's usage indicates, geography is always primary.

\section{CONTEMPORARY BIBLICAL SCHOLARSHIP.}

There is a steadily growing consensus among scholars that from a historical point of view, there were no Jews or Christians in the first century of the common era. Horsley (1994:398) affirms that insofar as Judaism in the New Testament bears and reflects rabbinicconcerns and expressions, Judaism did not yet exist. Contemporary Jewish scholars who choose to use the word for this period, insist on the plural: Judaisms, to highlight the historical fact that there was no monolithically uniform system of beliefs embraced by all who considered themselves members of the house of Israel. In this period, there was no single, standard expectation of 'the messiah' or a 'prophet of the end-time'.

Helmut Koester (1994:541-542) goes further and suggests that because of this diversity in the first century, the term 'Judaism' should be entirely removed from historical Jesus discussions. It is the ambiguous and imprecise understanding of this term that permits Jesus to be described as a precursor of the rabbis, a Hellenized Galilean Cynic, an apocalyptic Essene, or a messianic zealot. Instead, he suggests we speak of Israel understood as the 'sum total of the highly diversified phenomenon of various groups who were committed to the interpretation of the religious and cultural heritage of Israel'. This historically accurate picture is already evident in current publications (see Ord \& Coote 1994; Malina 1993; Malina \& Rorhbaugh 1992; and Pilch 1991, 1993, 1997). 


\section{CONCLUSION}

Westerners in general have a very poor sense of history. Teachers recognize that for their students history begins with their birth date, and all the past is fused into one amorphous mass of irrelevant information. Instilling a historical sense in students is a worthy task and a major accomplishment. Truly fortunate is the teacher who achieves that.

In the meantime, teachers and preachers are stuck with inaccurate and misleading translations that cause the kind of unnecessary problem described at the beginning of this article. It would seem a very prudent and responsible thing to do, at least when studying and reading the New Testament, to replace the erroneous translation 'Jew' in all instances with the more appropriate rendition: 'Judean'. This is already occurring in some books, but dedicated teachers should not wait for revised editions. The time to act is now.

\section{Works consulted}

Horsley, R A 1994. The Death of Jesus, in Chilton, B \& Evans, C A (eds), Studying the Historical Jesus, 395-422. Leiden: E J Brill.

Koester, H 1994. The Historical Jesus and the Historical Situation of the Quest: An Epilogue, in Chilton, B \& Evans, C A (eds) Studying the Historical Jesus, 535546. Leiden: E J Brill.

McKay, H A 1994. Sabbath and Synagogue: The Question of Sabbath Worship in Ancient Judaism. Leiden: E J Brill.

Malina, B J 1993. Windows on the World of Jesus: Time Travel to Ancient Judea. Louisville, KY: Westminster John Knox.

Malina, B J \& Rohrbaugh, R L. 1992. Social Science Commentary on the Synoptic Gospels. Minneapolis, MN: Fortress.

Ord, D R \& Coote, R B. 1994. Is the Bible True? Understanding the Bible Today. Maryknoll, NY: Orbis.

Pilch, J J. 1991. 'Resident Aliens' and 'Visiting Strangers'. The Bible Today 29, 357-361.

1993. Jews or Judeans: a translation challenge. Modern Liturgy 20, 19.

1997. The Cultural World of Jesus Sunday by Sunday: Cycle C: Luke. Collegeville, MN: Liturgical Press.

Von Wahlde, U C. 1981-82. The Johannine 'Jews': A Critical Survey. NTS 28, 3360. 